\title{
THE NAPA CHANGE MODEL: AN APPROACH TO EASE THE ORGANIZATIONAL CHANGE
}

\author{
Annisa Ratna Sari ${ }^{1}$ \\ Fakultas Ekonomi Universitas Negeri Yogyakarta
}

\begin{abstract}
ABSTRAK
Perubahan adalah suatu keharusan dalam sebuah organisasi dalam mempertahankan eksistensinya. Perubahan organisasi dapat berupa perubahan yang sistemik ataupun struktural, dan dapat dilakukan sendiri oleh organisasi tersebut maupun dengan bantuan konsultan. Dalam melakukan perubahan, dibutuhkan keberanian dari dalam diri organisasi untuk bertransformasi dari keadaan saat ini ke keadaan ideal yang diharapkan. Oleh karena itu, organisasi memerlukan sebuah model perubahan yang dapat dijadikan sebagai acuan dalam mengimplementasikan perubahannya. The NAPA Change Model merupakan model perubahan yang diajukan oleh penulis sebagai sebuah pendekatan yang dapat diadopsi agar perubahan dapat berjalan dengan baik. Model ini meliputi empat fase, yaitu fase pengenalan kebutuhan (Need Urgency), fase penilaian dan analisis (Assessment and Analysis), fase perencanaan (Planning), dan fase pelaksanaan (Action). Fase pengenalan kebutuhan dilakukan dengan cara membandingkan antara keadaan organisasi saat ini dengan keadaan ideal yang diharapkan oleh organisasi. Fase Penilaian dan analisis meliputi beberapa tahap analisis, yaitu analisis PEST, analisis SWOT, dan analisis Force Field. Fase perencanaan merupakan tahapan pengembangan strategi dan rencana aksi organisasi untuk mengelola transisi organisasi dari keadaan saat ini ke keadaan idealnya. Fase pelaksanaan merupakan fase dimana organisasi mulai melakukan perubahan berdasarkan desain yang sudah dibuat dalam fase sebelumnya. Kelebihan model ini adalah bahwa model ini menawarkan fleksibilitas kepada agen perubahan ataupun pemimpin perubahan untuk dapat melakukan refleksi, pengambilan kesimpulan, dan pengambilan keputusan selama proses pelaksanaan keempat fase yang sudah dijelaskan diatas.
\end{abstract}

Keywords: change model, organizational change, change process

\section{A. INTRODUCTION}

The first time people hear the word "change", it might lead one to something positive, like technology innovation. However, for some other people "change" is a forbidden word. Those people are terrified to leave something that is already integrated in their life as a custom, habit, or style. But nowadays, change is a necessity that one should endure if one expects to survive in this rapid changing world. Kotter (1996, p. 18) stated that, "the change which happen in this world such as information and technological revolution, the transpire of international economic integration and free market, the

\footnotetext{
${ }^{1}$ Staf Pengajar Jur. P. Akuntansi Fakultas Eekonomi Universitas Negeri Yogyakarta
} 
establishment of domestic market in developed countries, and the fall down of communism" drives the emergence of globalization. Hence, it force organizations to make striking improvement (i.e. organizational change) to compete, prosper and survive. Thus, in implementing the organizational change, the organization should start with drawing and inventing a change model as the guidance for change agents and change leaders to lead and facilitate the change efforts. The organization might also use any change model which is by now exist.

A change model is a simplified representation of the general steps that can be used as a guide for managers and consultants in initiating and carrying out a change process (Rothwell and Sullivan, 2005: 77). The change process itself may include a systemic change or a structural change. Change model is very important for organization to have since it consist of step-by-step direction for the organization to follow during the organizational change process. The organization is always allowed to go back.

\section{B. THE NAPA CHANGE MODEL}

This paper discusses a change model called the NAPA change model which can be seen in Figure 1 below. NAPA is an abbreviation of Need Urgency, Assessment and Analysis, Planning, and Action.

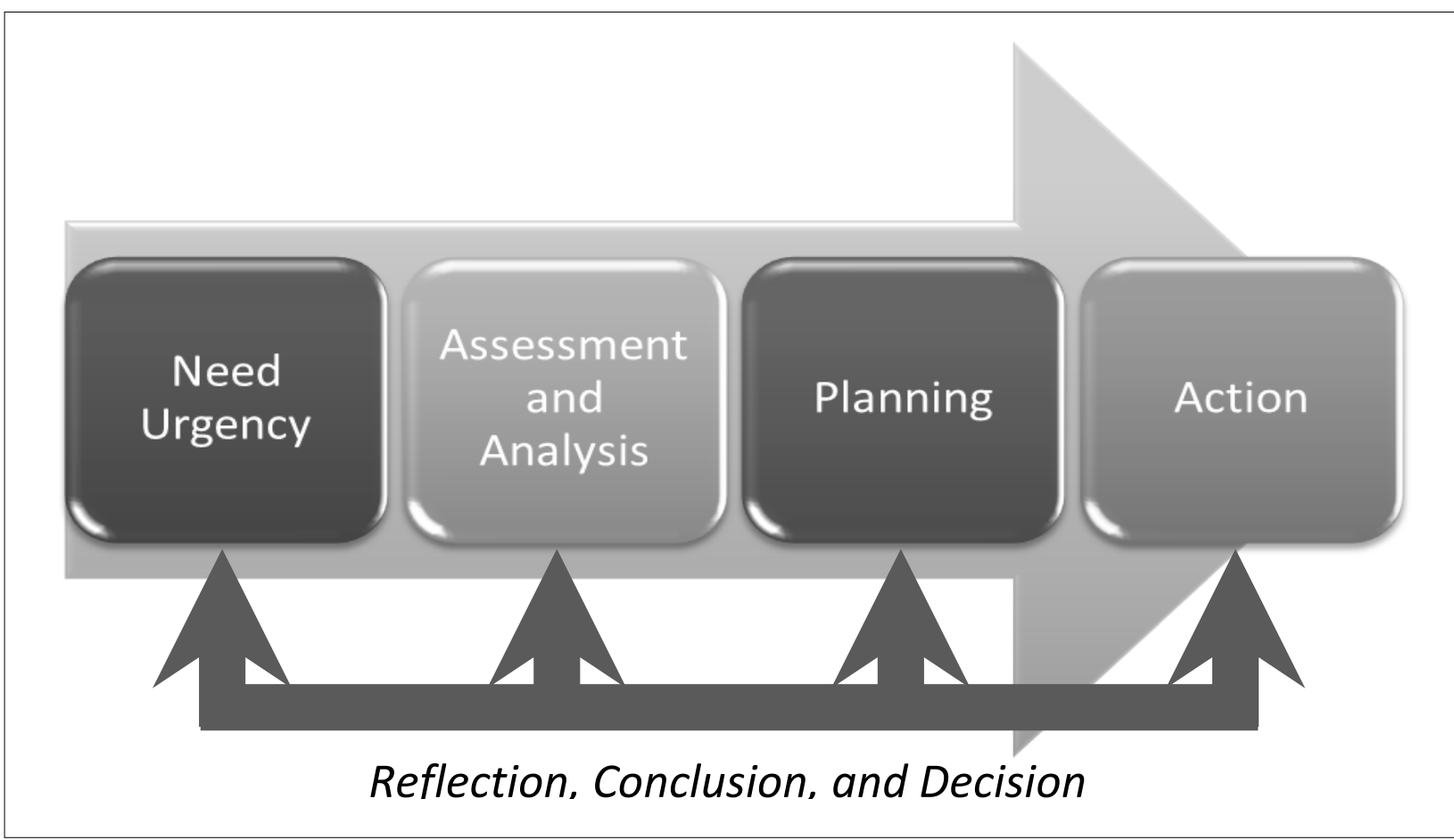

Figure1. The NAPA Change Model 
If one takes a look at Figure 1 above carefully, one then will recognize that the NAPA model lies on a big arrow. It means that one phase moves to another phase in a sequence order. It can also mean that this process represents a movement of an organizational change from its current state (i.e. before the change implementation) to another state (i.e. the ideal state that the organization wants). In this case, there are four big phases offered by NAPA Change Model including Need Urgency, Assessment and Analysis, Planning, and Action phase. The first phase is to understand the need of the organization continued with conducting the self assessment and analysis based on the data collected. The next step after the assessment and analysis is planning phase. This phase is related to organizational plan in employing organizational change. The next phase would be Action phase which refers to the implementation process of organizational change.

After completing the action phase, the change agent or the change leader is able to go back to redo the process. They may start from need urgency phase, assessment and analysis phase, or planning phase or action phase. But, before redoing the process, they must do reflection, conclusion, and decision making steps as the basis justification reason why they must redo it. The reason why the writer builds a change model that allows the consultant to go back and redo in any phase which they think need to redo is because she believes that change is a continuous process. The organization always wants to make their organization improved from time to time. Instead of building change processes individually, she would prefer to continue and use the self assessment and analysis result that has been done before to save money, time and energy.

The reflection will include examining the assumptions and raising relevant critical questions about the function and the reason of their existence; asking continuously whether their performance is effective; conducting a continuous assessment of the health of the organization; willing to explore, trying things out, or transform; promoting dialogue between the internal and external parties of the organization; able to accept disagreement and critics; exploring various improvement methods that fit with their organizational culture (Rothwell and Sullivan, 2005: 352). Then after the reflection is done, the organization can continue making generating conclusions based on the reflection results. And the last, deciding what kind of steps that the organization will take is based on the reflection results and conclusions. Hopefully, by following this process 
(i.e. reflection, conclusion, and decision making), the organization is able direct themselves to improve.

\section{NEED URGENCY PHASE}

The need urgency phase is a phase where the organization realizes their need. This need arrives when the organization realizes that their actual situation or state is different from what they are expected to be. Basically, this phase is about realizing the gap between their current state and their ideal state. The current state of the organization will include the organizational issues and needs, the organizational culture, and the basis that the organizational has in developing the vision (Rothwell and Sullivan, 2005: 252). The ideal state of the organization is the position of the organization intended to be where they value as the best circumstances.

Besides realizing the gaps, the need urgency phase also includes:

1. Commitment and contract making between the organization (i.e. client) and the consultant (i.e. change agent). The consultant might be an internal person in the organization or be hired from outside of the organization.

2. Understanding of the organizational mission, capability, resources, and politics.

Now, here is a description about the consultant's perspective. Being consultants for change, they must know how to place the position of themselves appropriately in the organization. The consultants are here to help the organization, so every step that they make is based on the culture of the organization not just based on their opinions. Here are some principles that can be followed by the consultants while doing their job helping the clients: "1) always try to provide help; 2) always understand the current reality; 3) willing to realize what they do not know about the organization; 4) always keep in mind that everything they do is an intervention, thus it might cause some consequences; 5) always bear in mind that it is the client who owns the problem and the solution; 6) always go along with the client's motivation and readiness; 7) must always consider the right timing; 8) being constructively opportunistic with the confrontive interventions; 9) remember that everything is based on data, therefore errors are inevitable -- but those can be the source of learning; 10) when in doubt, share the problem with the client" (Rothwell and Sullivan, 2005: 33). 


\section{ASSESSMENT AND ANALYSIS PHASE}

The assessment and analysis consists of two processes, i.e. the self-assessment process and the analysis process. The self-assessment process is a process where the consultant assessing the internal and external aspects of the organization, and also several forces which might influence the organization. The process then will be continued with analyzing all of the organizational aspects and forces. There are three methods that organization must do during this phase, i.e.:

1. PEST analysis $\rightarrow$ in this analysis, the consultant is making list of the political, economical, socio-cultural, and technological aspect that affect the organization from macro perspectives (Lin, 2006: 91).

2. SWOT analysis $\rightarrow$ basically, this analysis is making list of the strength, weaknesses, opportunity, and thread aspect that affect the organization. The strength and weaknesses are internal factors, while opportunity and thread are external factors (Leigh, 2010: 115-116).

3. Force field analysis $\rightarrow$ the force field analysis is done by listing the driving forces and restraining forces that influence the organization (Schwering, 2003: 361-362).

In conducting a self-assessment and analysis, various data will generated from the organization to find the root cause of the problem. Data can be collected from document analysis, interview, observation, and survey questionnaire. Below is the summarization of each method:

1. Document Review $\rightarrow$ is used to gather past and present existing published information; brochures; vision, mission, values, goals; organization chart; etc.

2. Questionnaires $\rightarrow$ is used to gather quantifiable data of organizations and its personnel by using set of questions in paper based of web based format.

3. Interviews $\rightarrow$ is used to gather quantitative data that is specific through detailed questions. Interview can be done in various ways, like individual interview, group interview, face to face, phone, or email.

4. Observations $\rightarrow$ is used to gather data by observing and talking to the object directly. This method is usually done if we want to see the real practice that occurs in the organization.

5. Assessments $\rightarrow$ is used to collect and analyze data that is currently happening. 
Each data collection method that the writer mentioned above have some advantages and disadvantages, consequently, before choosing what kind of method that one will use, each method must be weighed carefully because data collection take time and money. After all data are collected, then it has to be analyzed wisely, because the result of this analysis will determine the strategy alternatives for implementing the change.

As guidance to do the assessment and analysis phase, the writer will borrow the step by step process of organization assessment from Rothwell and Sullivan (2005: 275), but with the slight modification to fit in with the NAPA change model. The breakdown explanation of step by step process can be seen on the exhibit 1 below:

\section{Planning}

1. Assigning the right person to the right job responsibility

2. Determine the desired goals and outcomes of the assessments

3. Determine the data collect method

4. Determine data analyzing and reporting

5. Determine the feedback and data utilizing

6. Agree with leaders on the process and results utilization, and also guiding the leaders in leading the assessment process

7. Develop planning milestones

\section{Data Collection}

1. Everyone who is involved in the assessment must have been trained to do the assessment before

2. Make sure that the organization are ready for the assessment

3. Conducting the assessment

\section{Data Analysis}

1. Develop the best strategy for analyzing and presenting the assessment results to the client in a simple and understandable ways

\section{Data Feedback}

1. Design who will get the feedback from the assessment and analysis result and how

2. Prepare people for how to understand and utilize the data in helpful and positive ways to diffuse anxiety and ensure that the process will be beneficial and useful one 
Exhibit 1. Assessment and Analysis Phase

\section{PLANNING PHASE}

During the planning phase, the consultant must develop strategies and action plans that the organization ought to do in order to manage the organizational transition between the current states to the intended future states.

For the planning phase, the writer will also borrow the step by step process of action planning guidelines from Rothwell and Sullivan (2005: 275), but with the slight modification to fit in with the NAPA model of change. By following these steps, it will ensure that the consultant would be able to design the best strategies that the organization should obey. The step by step process can be seen on the exhibit 2 below:

Involve Key Stakeholders

1. Assigning the right person on the right job responsibility to be involved in the implementation phase

2. Assigning the leader for the change

3. Develop a change team

\section{Evaluate and Prioritize Relevant Data}

1. Develop an evaluation process and data prioritization

2. Clarify the change focus and the level of desired change

3. Focus on the present situation and the ideal situation that want to be achieve Agree on the Changes to be Made

1. Make an agreement on the action that will be taken in implementing the change

2. Using a system perspective to evaluate the change

3. Consider the change implication and the alignment needed Develop a Change Strategy

1. Identify the elements that support and resistance to change

2. Explore the strategy alternatives for change

3. Utilizing a change model as a guidance

4. Develop methods for monitoring and managing the change process

Clarify Roles and Follow-Through Responsibilities 
1. Clarify the roles and responsibilities for each member of change process

2. Make the change process clear and simple

3. Focus on the improvement of the health and effectiveness of the organization

Exhibit 2. Planning Phase

But before following the step by step process explains in the Exhibit 2 above, there are several points that the consultant must keep in mind. First is the guideline in making strategies and action plans, second is the various choice of intervention approach that can be used by the consultant in developing the strategy, and last is the type of the organization.

Beckhard and Harris in Rothwell and Sullivan (2005: 297) provide seven guidelines in making strategies and action plans: "1) the activities should be clearly linked to the goals and priorities of the identified change; 2) the activities should be clearly identified rather than broadly generalized; 3) discrete activities should be linked; 4) the activities should be time-sequenced; 5) contingent plans should exist in case unexpected forces develop during the change process; 6) the change plan should be supported by top management; 7) the plan should be cost-effective".

In terms of intervention approaches, French and Bell in Rothwell and Sullivan (2005: 320-321) describes five different interventions that can be done by the consultant, i.e.: interventions to improve the effectiveness of individuals, interventions to improve the effectiveness of DYADS/TRIADS, interventions to improve the effectiveness of teams and groups, interventions to improve the effectiveness of intergroup relations, interventions to improve the effectiveness of the total organization. The consultant must choose the right intervention for the organization in this planning phase.

In addition to the step by step planning process that already stated above, the consultant must also understand the type of the organization to help finding the root of the problem and also the strategies to resolve the problems in the organization. According to Rothwell and Sullivan there are four types of organizations, i.e.: ExploitiveAuthoritarian, Benevolent-Authoritative, Consultative, and Participative (2005: 30). By 
considering the various types of organization, it would make the consultant be easier in choosing the right strategies and action plans to fit with the organizational characteristics.

\begin{tabular}{|l|l|}
\hline $\begin{array}{l}\text { System 1: Exploitive-Authoritarian } \\
\text { - Dogmatic leadership }\end{array}$ & $\begin{array}{l}\text { System 2: Benevolent-Authoritative } \\
\text { - Manipulative use of rewards }\end{array}$ \\
- Top-down communication & \\
\hline $\begin{array}{l}\text { System 3: Consultative } \\
\text { - Management listens to employees, but reserves }\end{array}$ & - Leadership based on influence \\
the right to make decisions & - Intrinsic reward predominate \\
\hline $\begin{array}{l}\text { - Some reliance on intrinsic rewards most rewards } \\
\text { are based on extrinsic (money) rewards }\end{array}$ & - Two-way communication \\
\hline
\end{tabular}

Exhibit 3. Four type of Organizations

\section{ACTION PHASE}

The action phase is the time in which the organization is implementing the change based on the strategies and action plans that have been designed in the previous phase. During the action phase, there are some activities that should be done by the consultant, including: 1) making sure that the right people are present at the right place; 2) keeping in mind that the intervention is problem and opportunity oriented; 3 ) supervise the process; 4) engaging the participant in the problem solving activities; 5) making sure that participants are totally involved in the process and able to learn from it; 6) placing him/herself to be supporter and guide at the same time.

\section{CONCLUSION}

The NAPA change model is a model that can be used to guide the managers and consultants in initiating and carrying out a change process. This model consisted of four phases that are put in sequence, i.e.: Need Urgency, Assessment and Analysis, Planning, and Action. After the whole phases are completed, then the model allows the organization to make reflection, conclusion, and decision making as a basis justification to redo the 
process in any phase that is needed to redo. So, basically this model describes a continuous change process for organizational improvement.

\section{REFERENCES}

Kotter, J. P. (1996). Leading Change. Cambridge, MA: Harvard Business School Press.

Leigh, D. (2010). SWOT analysis. In R. Watkins \& D. Leigh (Eds.), Handbook of improving performance in the workplace, vol. 2: Selecting and implementing performance interventions (pp. 115-140). Silver Spring, MD: International Society for Performance Improvement.

Lin, H. (2006). Ethical applications of technology in HRD: A PEST analysis and implications. Performance Improvement Quarterly, 19(4), 91-106.

Rogers, E. M. (2003). Diffusion of Innovations. New York, NY: Free Press.

Rothwell, W. J., \& Sullivan, T. (2005). Practicing Organizational Development: A Guide for Consultants.(2 ${ }^{\text {nd }}$ Edition). San Fransisco, CA: John Wiley \& Sons.

Schwering, R. E. (2003). Focusing leadership through force field analysis: new variations on a venerable planning tool.Leadership \& Organization Development Journal, 24(7), 361-370 